\title{
Isotopic reconstruction of human diet at the Roman site (1st-4th c. AD) of Carrer Ample 1, Barcelona, Spain
}

\author{
Carme Rissech $^{\mathrm{a}, *}$, Aniol Pujol ${ }^{\mathrm{b}}$, Niel Christie ${ }^{\mathrm{a}}$, Lluis Lloveras ${ }^{\mathrm{a}, \mathrm{c}}$, Michael P. Richards ${ }^{\mathrm{d}, \mathrm{e}}$, Benjamin T. Fuller ${ }^{\mathrm{d}, \text { f, g }}$ \\ a School of Archaeology and Ancient History, University of Leicester, Leicester, UK \\ b Biological Anthropology Unit, Department of Animal Biology, Barcelona University, Barcelona, Spain \\ ' SERP, Department of Prehistory, Ancient History and Archaeology, Faculty of Geography and History, Barcelona University, Barcelona, Spain \\ d Department of Human Evolution, Max Planck Institute for Evolutionary Anthropology, Deutscher Platz 6, D-04103 Leipzig, Germany \\ e Department of Archaeology, Simon Fraser University, Burnaby, British Columbia V5W 1S6, Canada \\ ${ }^{\mathrm{f}}$ Laboratory of Biodiversity and Evolutionary Genomics, Centre for Archaeological Sciences, Katholieke Universiteit Leuven, Ch. Debériotstraat 32, B-3000 Leuven, Belgium \\ ${ }^{g}$ Department of Archaeology and Anthropology, University of Chinese Academy of Sciences, Beijing 100049, China
}

\section{A R T I C L E I N F O}

\section{Article history:}

Received 5 May 2016

Received in revised form 6 July 2016

Accepted 18 August 2016

Available online $\mathrm{xxx}$

\section{Keywords:}

Stable isotopes

Palaeodiet

Breastfeeding

Weaning

Fish consumption

Roman

Archaeology

Barcelona

Spain

\section{Introduction}

Much of our knowledge about diet in Classical Antiquity is derived from ancient texts, such as De re coquinaria from Apicius; literature on medical treatments; works of art, especially wall and vase painting and Roman mosaics; and from archaeological evidence in the form of faunal and plant remains, food preparation utensils, and storage vessels (Keenleyside et al., 2009). While these sources provide valuable information on the types of foods that were available and how they were prepared for consumption, they cannot tell us, with certainty, what foods were actually eaten. For this reason, stable isotope ratio analysis of collagen from human skeletal remains has become a routine technique in bioarchaeology to identify and define certain types of foods consumed (e.g. Katzenberg, 2000; Lee-Thorp, 2008). These isotopic results primarily reflect the protein component of the diet averaged over the entire lifetime of an individual, including a large portion of collagen synthesized during later childhood and adolescence (Stenhouse and Baxter, 1979; Hedges et al., 2007). However, recent studies have shown that nearly $40 \%$ of the carbon in bone collagen can originate from non-protein sources (Froehle et al.,

\footnotetext{
* Corresponding author at: Depertament de Ciències Mèdiques, Facultat de Medicina, Universitat de Girona, Emili Grahit, 77, 17071 Girona, Spain.

Email address: carme.rissech@gmail.com (C. Rissech)
}

2010). Briefly, stable isotope ratios are defined as the ratio of the heavier to the lighter isotope $\left({ }^{13} \mathrm{C} /{ }^{12} \mathrm{C}\right.$ or $\left.{ }^{15} \mathrm{~N} /{ }^{14} \mathrm{~N}\right)$ and are compared in terms of $\delta$ values in parts per 1000 or "per mil" (\%o) in relation to internationally defined standards for carbon (Vienna Pee Dee Belemnite, VPDB) and nitrogen (Ambient inhalable Reservoir, AIR) (Schwarcz and Schoeninger, 1991). An in-depth discussion on the use of stable isotope ratios to reconstruct past diets is beyond the focus of this paper but a variety of reviews are available to provide such detail (e.g. Katzenberg, 2000; Lee-Thorp, 2008; Reitsema, 2013, 2015; Canti and Huisman, 2015).

Stable carbon and nitrogen isotope ratio analysis has been used to study Roman populations, mainly to (1) determine the proportion of marine vs. terrestrial foods in the diet (e.g. Richards et al., 1998; Prowse et al., 2004; Craig et al., 2009; Keenleyside et al., 2009; Crowe et al., 2010; Redfern et al., 2010); (2) examine age and sex-based differences in diet (e.g. Prowse et al., 2005; Cheung et al., 2012; Killgrove and Tykot, 2013; Müldner, 2013); (3) investigate infant feeding practices (e.g. Dupras et al., 2001; Dupras and Tocheri, 2007; Fuller et al., 2006a; Prowse et al., 2008); and (4) examine temporal changes in diet (e.g. Richards et al., 1998; Fuller et al., 2010, 2012a; Redfern et al., 2010). However, while the use of isotopic measurements for palaeodiet reconstruction has increased over the past decade, only a small number of studies have so far focused on sites from Spain and most of these were from the Balearic Islands (Davis, 
2002; Van Strydonck et al., 2002, 2005; Márquez-Grant et al., 2003; Garcia et al., 2004; Fuller et al., 2010; Nehlich et al., 2012), Canary Islands (Arnay-de-la-Rosa et al., 2009) and from prehistoric contexts (Arias and Schulting, 2010; Salazar-García et al., 2013, 2014). Little research has been published on mainland Spanish Roman skeletal assemblages, but see López-Costas (2012) and Salazar-García et al. (2016).

Here we present carbon and nitrogen isotopic results for a sample of humans $(\mathrm{n}=23)$ and animals $(\mathrm{n}=21)$ from the site of Carrer Ample 1 in the city of Barcelona, Spain. The objective of this preliminary report is to examine the dietary patterns of this population; in particular, do the data support the historical accounts of the Mediterranean Roman diet such as the prominent consumption of marine foods, given that the site was located on the Mediterranean coast? We then review the literature to compare the Carrer Ample 1 results with other coastal Roman sites to examine dietary patterns across the Roman Empire.

\subsection{Archaeological, historical, and geographical background}

Barcelona lies on the northeast of the Iberian Peninsula, in the central third of the Catalonian coast, between the Llobregat River (to the south) and the Besos River (to the east), and it is bordered in the north by the Collserola mountain range (Fig. 1). Established by the emperor Augustus in the year $14 \mathrm{BCE}$, the Roman colony of Barcelona was officially called Colonia Iulia Augusta Paterna Fauentia Barcino or simply Barcino (Hernández, 2001). Barcino was erected on a small hillock called Mont Taber in the Middle Ages $(15 \mathrm{~m}$ above sea level) covering an area of approximately 10 ha. Barcino had the usual architectural structure of a Roman colony: the enclosure was overall rectangular, although the angles were adapted to fit the shape of the hillock (Fig. 1) and two main streets ran out from the four gates and formed a cross [Decumanus Maximus and Cardo Maximus, (Hernández, 2001)]. The Decumanus Maximus extended along the axis of the mountain to the sea, now occupied by the streets of Carrer Bisbe, Carrer de la Ciutat and Carrer Regomir. The Cardo Maximus extended along the perpendicular axis to the Decumanus Maximus (Besòs-Llobregat), corresponding to today's Carrer Libreteria and Carrer del Call streets. There were four gates in total. The Decumanus Maximus had the Porta Praetoria in the northwest and Porta Decumana (or Sea Gate) in the southeast. The Sea Gate was the main gateway to the city. The Cardo Maximus had the westerly Porta Principalis Dextra and the Porta Principal Sinistra situated in the east. The surrounding territory (ager) was divided into plots and subjected to intense agricultural exploitation by the colonists and later by numerous villae. Important commercial products produced in the area included cereals and wine, plus iron from the Gavà mines
(Gavà is a city located west of Barcelona), and clay from Montjuic (a steep hill overlooking Barcelona to the southwest) which was the preferred building material in the majority of the Barcino buildings (Álvarez and Estrada, 2009; Bordas et al., 2009). Trade and commerce were crucial to the subsequent development of the city and the Llobregat River was an important means of communication to the interior of Catalonia (Keay, 1984). Finally, seafaring and fishing were also important industries for Barcino, and the city was renowned for its oysters (Sánchez, 2005; Fuertes-Prieto and Fernández-Rodríguez, 2010). The city saw continuity into the late Roman and Visigothic period and had a strong Christian presence (Hernández, 2001).

As was customary in Roman cities, the necropolises of Barcino were located outside of the city wall but along the main roads. The higher social status individuals had burial spaces nearest to the gates. Two main cemetery areas have been located so far in Barcelona. One is situated in the northeast of Barcino and is related to the Porta Principal Sinistra and the Riverside Neighbourhood with an important necropolis called Villa de Madrid with 90 tombs excavated (Fig. 1d, C). The other area lies to the southwest of Barcino and is related to the Sea Gate (Triay-Oliver, 2006; Juárez-Arroyo, 2009; Prida, 2009). It was discovered by rescue excavations at several sites: Anselm Clavé Street, Passeig de la Pau and Carrer Ample 1 (Fig. 1d, A). This area of the necropolis is currently called Via Sepulcral de la Porta del Mar. the Sea Gate cemetery road.

\subsection{The site of Carrer Ample 1}

As a result of a rescue excavation by ArqueoCat SL between 2007 and 2008, a portion of a 2nd century A.D. Roman necropolis was discovered on Carrer Ample street (hence the name), immediately southwest of the Roman city (Triay-Oliver, 2006; Juárez-Arroyo, 2009; Prida, 2009). The entire site dates between the 1 st -4 th century A.D., and is related to seafaring activities during the foundation period (1st century) of the Roman colony of Barcino. In total, 24 individual Roman graves were recovered and these had a varied typology of burial styles - pitched roof, partially built tombs with head and foot stones or tegulae (flat Roman tiles), with or without coffins with stone and/or tegula roof covers, and simple earth-cut graves - characterized by their simplicity and absence of grave-goods. The deceased were buried in an extended supine position, with the head pointed to the northwest and feet to the southeast. The burials were dated between the 2 nd -4 th c. A.D on the basis of the archaeological data obtained during the excavation (Pujol-Bayona et al., 2011). The layout of the funerary complex did not reveal any specific pattern or distribution according to burial typology, age or sex (Fig. 2). The skeletal remains were subjected to osteological examination by Pujol-Bayona et al. (2011).
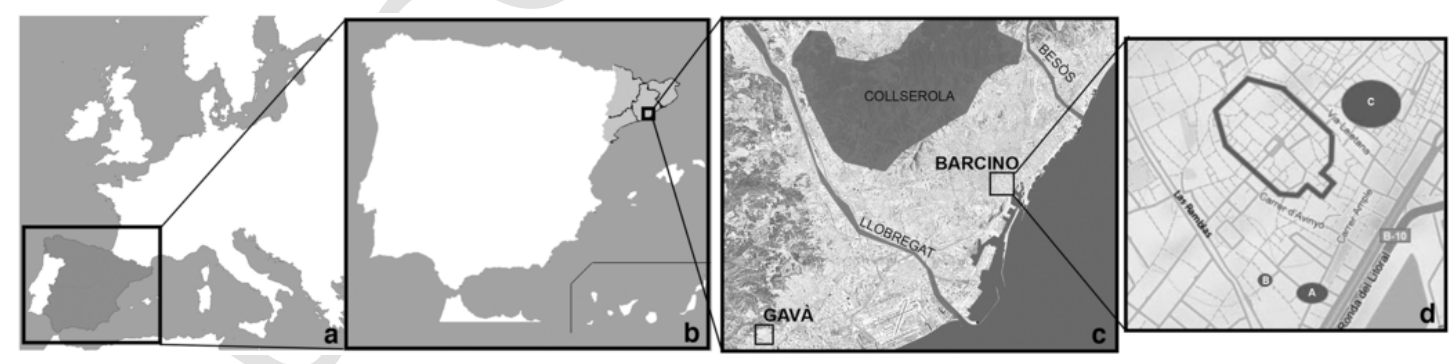

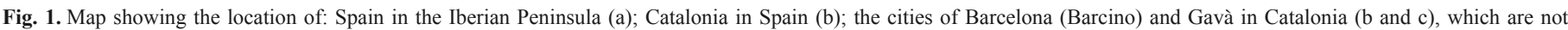

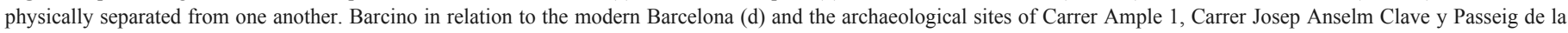
Pau (A); Early Imperial Villa (B); the Riverside Neighbourhood (Barri de Ribera) necropolis and Sta. María del Mar church (C). 


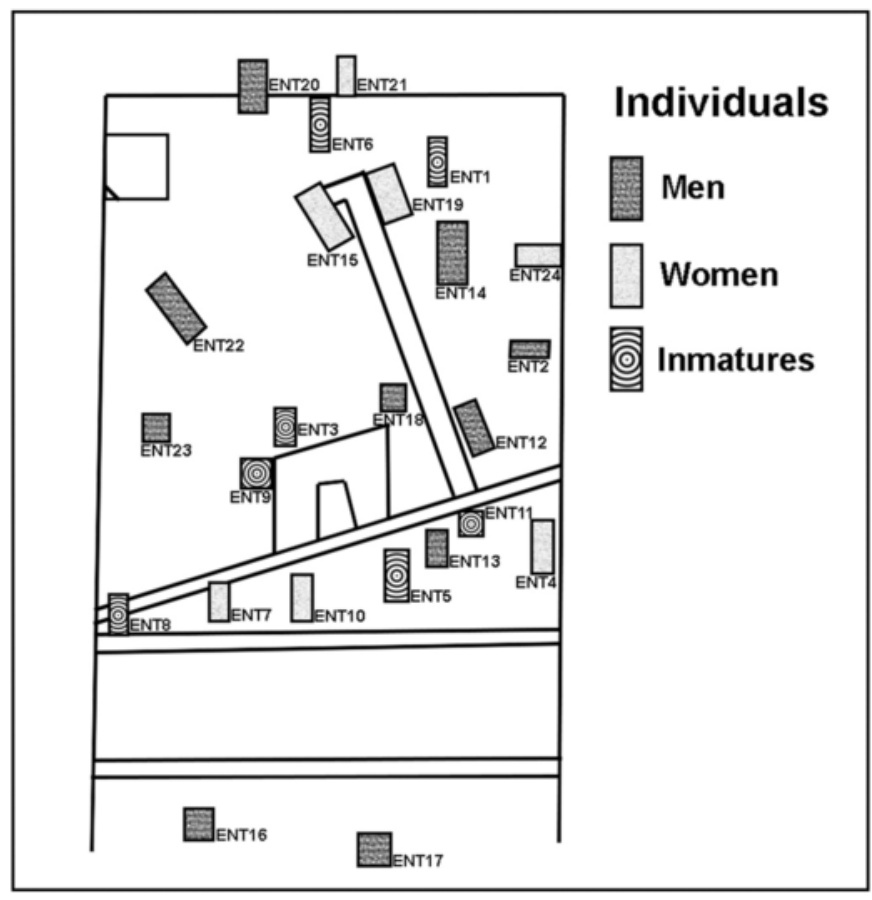

Fig. 2. Carrer Ample 1 site map showing the locations of the 24 tombs differentiated by males, females and infants.

\subsection{Roman diet}

Much of the information that we have on Roman diet comes from ancient texts (see Giacosa, 1994; Faas, 1994; Garnsey, 1999; Alcock, 2006; Cool, 2006; Wilkins and Hill, 2006). For example, the recipe book of Apicius (The Art of Cooking) describes gourmet meals; the physician Galen (129-200 A.D) wrote about the medical properties of certain foods (On the Properties of Foodstuffs), and the writers in Athenaeus' The Learned Banqueters compared different dishes. It is important to note that all these texts were written by and for the upper classes, with most describing the culinary customs of contemporary Italy or the eastern Mediterranean. Moreover, moralizing agendas can influence an author's view of food in the present and past (Purcell, 2003; Wilkins and Hill, 2006). Therefore, one must be cautious when attempting to extrapolate the culinary customs and practices of specific archaeological populations, often of lower classes, at a specific place and period of time. Furthermore, it is well known that Roman provincial residents both adopted new value-systems and maintained continuity with former ways of life in a rather complex fashion and in relation to class, gender, status and age categories (Woolf, 1998; Cool, 2006; Mattingly, 2006; Van der Veen, 2008).

As the documentary sources indicate, what can be termed as the Roman diet focused on a Mediterranean triad made up of cereals, olive oil, and wine, together with legumes including broad beans, lentils, chick peas and garden peas (Faas, 1994; Garnsey, 1999). Wheat and barley were the source of dietary protein, and bread was made using a variety of cereals (Faas, 1994). Millet, a cereal that thrives in dry conditions, was consumed in some parts of Eastern and Southern Europe (Murray and Schoeninger, 1988; Schoeninger and Moore, 1992; Mays, 1998) as well as in the north-eastern region of the Iberian Peninsula (Alonso, 2000). Olive oil was the main source of dietary fat and was used in almost every dish (Faas, 1994). Cheese made from goat and sheep milk was a popular food item, and geese and chickens provided eggs (Faas, 1994). The Romans also ate a va- riety of fruits, vegetables, and nuts, and honey was the main sweetener (Van der Veen, 2008). Wine was widely consumed but was usually diluted with water. Meat, at least in the broad Mediterranean context, derived primarily from pigs, and in lesser quantity from sheep and goats (Faas, 1994; Garnsey, 1999). The proportion of different kinds of meat consumed varied by region, class, and site type (King, 1999; MacKinnon, 2004). Fish preserved, fermented or salted, were important across the whole Roman period. In the coastal provinces of Hispania (the Roman Iberian Peninsula), great quantities of fish were obtained and prepared, often then to be distributed to the urban centers; different fish sauces such as garum were prepared. Garum was a fish paste which accompanied a variety of dishes (Garnsey, 1999). One of the biggest garum (garum hispanum) and salting factories of Hispania was in Baelo Claudia (today's Cádiz). However, in Roman times, fish (by itself) was not a staple foodstuff as the bulk of the population were farmers, not fishermen, so the consumption of fish was not common in many areas. Instead fish was considered an important dietary supplement in fishing villages and for city dwellers. However, some kinds of fish and shellfish were considered a delicacy, and this led to the construction of salt and freshwater fish farms to breed species valued by the wealthy, such as the cultivation of oysters on the coast of Barcino (Fernandez-Rodríguez et al., 1998; Genera-Monells et al., 2010).

The ancient literary texts also show class differences could exist in both the quantity and quality of the foods consumed (Garnsey, 1999). For example, barley was considered of inferior status than wheat and as a consequence barley was eaten frequently by the lower classes (Dalby, 2003). In contrast, meat was a food of prestige which was an important component of the diet among members of the upper class (Garnsey, 1999). Wealthy individuals also had a more varied diet overall drawing especially on diverse wines, olive oils and wild game. Presentation, preparation, variety, and spicing were fundamental ways among the elite to distinguish luxury dining (Dunbabin, 2003; Sánchez, 2005).

\section{Material and methods}

Samples for stable isotope ratio analysis were collected from the ribs or, if no ribs were available, from diaphyseal long bone fragments from the 24 individuals at Carrer Ample 1. Sex and age estimation for each of the skeletons was determined according to standard methods (e.g., Buikstra and Ubelaker, 1994; Brickley and McKinley, 2004; Rissech et al., 2006, 2007, 2013). For a detailed methodology see Pujol-Bayona et al. (2011). To understand the trophic context for the human isotope data, a total of 26 faunal bone samples from consumption refuse excavated at the site and identified by Lluís Lloveras was analyzed. The samples consisted of bones of cattle, pigs, sheep/ goat, chickens, red deer, and unidentified birds. They were used in order to establish baseline isotopic data against which the human isotopic values could be compared.

Bone collagen from these 24 humans and 26 animals was isolated at the Department of Human Evolution, Max Planck Institute for Evolutionary Anthropology in Leipzig, Germany, using the protocol described in Richards and Hedges (1999), modified to include a final stage of ultrafiltration prior to lyophilisation (Brown et al., 1988). The extracted collagen was well preserved and the majority of samples had collagen yields of over $1 \%$ and $\mathrm{C}: \mathrm{N}$ between 2.9 and 3.6 (21/26 animals; 23/24 humans), which is indicative of collagen suitable for isotopic analysis (DeNiro, 1985). The purified collagen was then placed in tin capsules and combusted in duplicate in separate runs to $\mathrm{CO}_{2}$ and $\mathrm{N}_{2}$ in an automated carbon and nitrogen analyzer (Carlo Erba) coupled to a continuous-flow isotope ratio-monitoring 
mass spectrometry (PDZ Europa Geo 20/20). Replicate measurement errors on known standards were $<0.2 \%$ for both $\delta^{13} \mathrm{C}$ and $\delta^{15} \mathrm{~N}$ values. Samples were then statistically analyzed by non-parametric Mann-Whitney U tests. Where more than two groups were compared, nonparametric Kruskal-Wallis H one-way ANOVA tests were applied and followed up in case of significance by Bonferroni-adjusted Mann-Whitney post hoc tests. Results were considered significant at $\mathrm{p} \leq 0.05$.

\section{Results}

The acceptable $\delta^{13} \mathrm{C}$ and $\delta^{15} \mathrm{~N}$ results from the 21 fauna and $23 \mathrm{hu}-$ mans are listed in Tables 1 and 2 and plotted in Fig. 3. Given that Carrer Ample 1 was a rescue excavation, the number of skeletal remains available for study was relatively small, but they permit an important understanding of the isotopic ecology of the site as well as a first understanding of the human diet during the Imperial Roman period (2nd -4 th c. A.D) at Barcelona.

\subsection{Fauna}

Stable isotope ratio analysis of the 21 faunal samples (Table 2) yielded $\delta^{13} \mathrm{C}$ values ranging from $-22.0 \%$ to $-18.4 \%$ o (mean $\pm \mathrm{SD}=-19.5 \pm 2.3 \%$ ) and $\delta^{15} \mathrm{~N}$ values ranging from $1.9 \%$ to $10.3 \%$ o (mean $\pm \mathrm{SD}=4.8 \pm 2.4 \%$ ). These values are similar to those measured in archaeological and modern samples from other sites around the Mediterranean (e.g. Garvie-Lok, 2001; Prowse et al., 2004; Keenleyside et al., 2009), and fall within the range of southern European terrestrial herbivores that feed on $\mathrm{C}_{3}$ plants such as barley.
The cattle have some of the most ${ }^{13} \mathrm{C}(-22.0 \%$ to $-20.6 \%$ ) and ${ }^{15} \mathrm{~N}$-depleted $(1.9 \%$ o to $3.5 \%$ ) values of all the animals studied. The six pig results have similar $\delta^{13} \mathrm{C}$ values $(-20.3 \%$ to $-19.4 \%$ ) but a large range in $\delta^{15} \mathrm{~N}$ values $(4.3 \%$ to $8.7 \%$ ). The two pigs with the highest $\delta^{15} \mathrm{~N}$ values $(7.3 \%$ and $8.7 \%$ ) could have consumed human refuse, something observed at other Roman sites (Fuller et al., 2012a). The two sheep/goats also have similar $\delta^{13} \mathrm{C}$ values $(-20.6 \%$ o and $-20.3 \%$ ) but different $\delta^{15} \mathrm{~N}$ values (3.9\%o and 6.2\%o). Given the small sample size it is difficult to make secure conclusions, but the sheep/goats with the ${ }^{15} \mathrm{~N}$-enriched values might also indicate some human refuse consumption. A single chicken was analyzed, and it had the most ${ }^{13} \mathrm{C}\left(-18.6 \%\right.$ ) and ${ }^{15} \mathrm{~N}$-enriched $(10.3 \%$ ) values of all the domestic animals studied. This chicken plots with the human isotopic results, and this might indicate that it was consuming a human diet, possibly in the form of leftovers, also a conclusion made at other Roman sites (e.g. Müldner and Richards, 2007; Fuller et al., 2012a). The red deer have a very tight range of $\delta^{13} \mathrm{C}$ values $(-20.2 \%$ o to $-19.9 \%$ ) and a small range in $\delta^{15} \mathrm{~N}$ values $(2.7 \%$ to $4.4 \%$ ). The three birds display the largest range of $\delta^{13} \mathrm{C}$ values $(-18.4 \%$ to $-10.8 \%$ ) but a much smaller range in $\delta^{15} \mathrm{~N}(5.9 \%$ to $7.9 \%$ ). These bird bones could not be identified to species, but their ${ }^{13} \mathrm{C}$-enriched measurements suggest that they had a marine protein diet and so were likely seabirds.

\subsection{Adult humans}

The 15 adult humans studied (Table 1) have a narrow $\delta^{13} \mathrm{C}$ $(-19.5 \%$ to $-18.4 \%$; mean $\pm \mathrm{SD}=-18.9 \pm 0.3 \%$ o $)$ and $\delta^{15} \mathrm{~N}$

Table 1

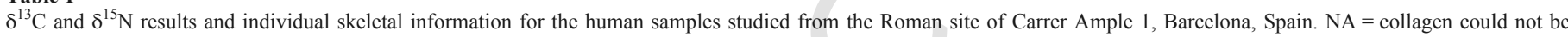
isolated.

\begin{tabular}{|c|c|c|c|c|c|c|c|c|}
\hline $\begin{array}{l}\text { S-EVA } \\
\#\end{array}$ & $\begin{array}{l}\text { Sample } \\
\text { ID }\end{array}$ & Sex & $\begin{array}{l}\text { Age } \\
\text { (years) }\end{array}$ & $\begin{array}{l}\delta^{13} \mathrm{C} \\
(\% o)\end{array}$ & $\begin{array}{l}\delta^{15} \mathrm{~N} \\
(\% o)\end{array}$ & $\mathrm{C}: \mathrm{N}$ & Burial type & Skeletal information \\
\hline 7197 & ENT3 & Female (?) & $0.5-1$ & -19.0 & 14.2 & 3.4 & $\begin{array}{l}\text { Roof cover of stones and tegulae (flat Roman } \\
\text { tile) }\end{array}$ & \\
\hline 7203 & ENT9 & Unknown & $1-1.5$ & -18.7 & 16.1 & 3.3 & Simple grave & Vertebral fusion (thoracic) \\
\hline 7195 & ENT1 & Female (?) & $4-5$ & -19.0 & 11.3 & 3.2 & Pitched roof & \\
\hline 7202 & ENT8 & Female (?) & $4-5$ & -18.6 & 13.0 & 3.2 & Pitched roof & Left triquetral and lunate bone fusion \\
\hline 7199 & ENT5 & Male (?) & $7-8$ & -19.2 & 10.1 & 3.2 & Pitched roof & \\
\hline 7200 & ENT6 & Female (?) & $8-9$ & -19.1 & 10.6 & 3.2 & Pitched roof & \\
\hline 17,260 & ENT21 & Female & $8-10$ & -18.7 & 9.1 & 3.2 & Pitched roof & \\
\hline 7205 & ENT11 & Unknown & $9-10$ & -20.0 & 8.9 & 3.2 & Simple grave & \\
\hline 17,261 & ENT24 & Female & $>20$ & -19.1 & 10.4 & 3.4 & Roof cover of tegulae (flat Roman tile) & \\
\hline 17,258 & ENT16 & Male & $>20$ & -19.0 & 10.6 & 3.2 & Simple grave & \\
\hline 17,259 & ENT17 & Male & $>20$ & -18.5 & 10.7 & 3.3 & Simple grave & \\
\hline 7204 & ENT10 & Female & $20-25$ & -19.0 & 11.1 & 3.3 & Pitched roof & Right radius fracture \\
\hline 17,745 & ENT18 & Male & $20-40$ & -19.0 & 10.6 & 3.2 & $\begin{array}{l}\text { Partially built tomb with head and feet tegulae } \\
\text { (flat Roman tile) }\end{array}$ & \\
\hline 17,747 & ENT20 & Male & $24-28$ & -18.5 & 10.8 & 3.2 & Pitched roof & \\
\hline 17,749 & ENT23 & Male & $24-28$ & -18.7 & 10.9 & 3.2 & Simple grave & \\
\hline 7207 & ENT13 & Male & $25-30$ & -18.8 & 11.0 & 3.3 & Simple grave & \\
\hline 7201 & ENT7 & Female & $25-30$ & -18.8 & 11.4 & 3.2 & Pitched roof & Left radius \& ulna fracture \\
\hline 7198 & ENT4 & Female & $35-40$ & -19.2 & 11.6 & 3.2 & Build tomb with tegulae (flat Roman tile) & Triquetral \& lunate fusion in both hands \\
\hline 17,746 & ENT19 & Female & $35-40$ & NA & NA & NA & Partially built tomb with head and feet stones & \\
\hline 17,743 & ENT14 & Male & $50-55$ & -18.6 & 11.3 & 3.3 & Simple grave & \\
\hline 7196 & ENT2 & Male & $50-55$ & -19.3 & 11.6 & 3.3 & Pitched roof & \\
\hline 17,744 & ENT15 & Female & $55-60$ & -19.1 & 10.8 & 3.3 & $\begin{array}{l}\text { Partially built tomb with head and feet tegulae } \\
\text { (flat Roman tile) }\end{array}$ & Right radius fracture \\
\hline 7206 & ENT12 & Male & $55-60$ & -19.5 & 10.7 & 3.4 & Simple grave & $\begin{array}{l}\text { Left clavicle fracture, probable osteoma ( } 1 \mathrm{~mm} \text { diameter) } \\
\text { in occipital bone. }\end{array}$ \\
\hline 17,748 & ENT22 & Male & $60-65$ & -18.4 & 11.7 & 3.3 & $\begin{array}{l}\text { Partially built tomb with head and feet tegulae } \\
\text { (flat Roman tile) }\end{array}$ & 5 th right metacarpal fracture (hand) \\
\hline
\end{tabular}


Table 2

$\delta^{13} \mathrm{C}$ and $\delta^{15} \mathrm{~N}$ results for the fauna from the Roman site of Carrer Ample 1, Barcelona, Spain. The investigated species include: pig (Sus scrofa f. domestica), red deer (Cervus elaphus), sheep/goat (Ovis ammon $\mathrm{f}$. aries/Capra aegagrus $\mathrm{f}$. hircus), chicken (Gallus gallus $\mathrm{f}$. domestica), cow (Bos primigenius f. taurus), and unidentified bird species. $\mathrm{NA}=$ collagen could not be isolated and crossed out results are not useable due to poor $\mathrm{C}: \mathrm{N}$.

\begin{tabular}{lllll}
\hline S-EVA \# & Species & $\delta^{13} \mathrm{C}(\%)$ & $\delta^{15} \mathrm{~N}(\% \circ)$ & $\mathrm{C}: \mathrm{N}$ \\
\hline 7208 & Pig & -19.4 & 4.4 & 3.1 \\
7209 & Pig & -20.2 & 8.7 & 3.4 \\
23,809 & Pig & -20.0 & 7.3 & 3.3 \\
23,810 & Pig & -19.9 & 4.3 & 3.3 \\
23,811 & Pig & -20.3 & 3.0 & 3.3 \\
23,812 & Pig & -20.3 & 4.8 & 3.3 \\
23,813 & Pig & $N A$ & $N A$ & $N A$ \\
7210 & Red deer & -20.2 & 4.4 & 3.4 \\
23,822 & Red deer & -20.0 & 2.7 & 3.2 \\
23,823 & Red deer & -20.1 & 3.5 & 3.2 \\
23,824 & Red deer & -19.9 & 2.2 & 3.2 \\
23,825 & Red deer & -20.1 & 2.9 & 3.4 \\
7211 & Sheep/Goat & -20.3 & 6.2 & 3.4 \\
23,806 & Sheep/Goat & $N A$ & $N A$ & $N A$ \\
23,807 & Sheep/Goat & -20.6 & 3.9 & 3.3 \\
23,808 & Sheep/Goat & $N A$ & $N A$ & $N A$ \\
7212 & Chicken & -18.6 & 10.3 & 3.5 \\
23,814 & Cow & -22.0 & 1.9 & 3.4 \\
23,815 & Cow & -20.7 & 2.8 & 3.3 \\
23,816 & Cow & -21.1 & 3.5 & 3.3 \\
23,817 & Cow & -20.6 & 2.8 & 3.2 \\
23,818 & Unknown bird & -10.8 & 7.9 & 3.3 \\
23,819 & Unknown bird & -18.4 & 5.9 & 3.3 \\
23,820 & Unknown bird & -18.5 & 7.4 & 4.1 \\
23,821 & Unknown bird & -15.8 & 7.5 & 3.3 \\
23,826 & Unknown bird & -11.9 & 8.9 & 13.6 \\
\hline & & & &
\end{tabular}

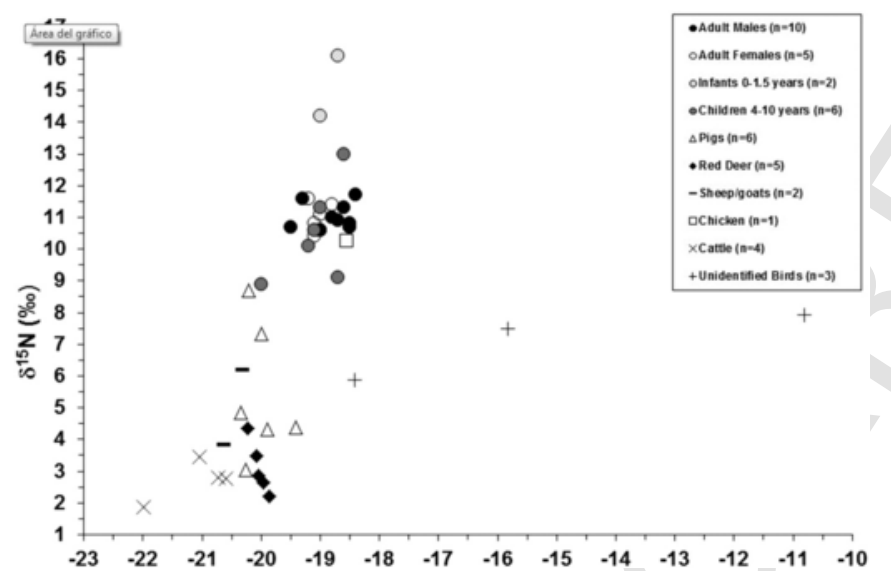

Fig. 3. Plot of $\delta^{13} \mathrm{C}$ and $\delta^{15} \mathrm{~N}$ results for Roman (1st-4th c. AD) fauna and humans from the site of Carrer Ample 1 Barcelona, Spain.

$(10.4 \%$ o to $11.7 \%$; mean $\pm \mathrm{SD}=11.0 \pm 0.4 \%$ ) range that is evidence of a homogenous terrestrial $\mathrm{C}_{3}$ protein diet based on the domestic animals. Due to the small sample size of this rescue excavation study, it is difficult to comment on the types of animals consumed, but it seems that both chicken (high $\delta^{15} \mathrm{~N}$ value) and cattle/deer (low $\delta^{15} \mathrm{~N}$ values) were not readily eaten by this population and that pigs and possibly sheep/goats were the main dietary protein sources. This is in agreement with the historical sources (see Roman diet section above). There is little evidence for $\mathrm{C}_{4}$ or marine foods in the diet of this population, and this is interesting given the proximity of this population to the coast and since other studies have identified both $\mathrm{C}_{4}$ and/or marine food consumption during the Roman period (Richards et al., 1998; Prowse et al., 2004; Craig et al., 2009;
Keenleyside et al., 2009; Crowe et al., 2010; Redfern et al., 2010; Cheung et al., 2012; Killgrove and Tykot, 2013; Müldner, 2013; Rissech et al., 2013). No significant differences in the isotopic values were observed between males $\left[\delta^{13} \mathrm{C}(-18.0 \pm 0.4 \%)\right.$ and $\delta^{15} \mathrm{~N}$ $(10.9 \pm 0.5 \%)]$ and females $\left[\delta^{13} \mathrm{C}(-19.0 \pm 0.0 \%)\right.$ and $\delta^{15} \mathrm{~N}$ $(11.1 \pm 0.5 \%)]$ from Carrer Ample 1 , with a $\mathrm{p}=0.156$ for $\delta^{13} \mathrm{C}$ and $\mathrm{p}=0.712$ for $\delta^{15} \mathrm{~N}$.

\subsection{Infants and children}

The two infants have elevated $\delta^{15} \mathrm{~N}$ values, and this reflects the fact that they were still being breastfed prior to their death (Fuller et al., 2006a). A total of six children from Carrer Ample 1 between the ages of 4-10 years were also isotopically studied. One child (ENT 8), aged between 4 and 5 years, shows an elevated $\delta^{15} \mathrm{~N}$ value, possibly indicating that breastmilk was still consumed at the time of death. Three children have carbon and nitrogen results identical to the adult population, but the two oldest children between 8 and 10 years old show ${ }^{15} \mathrm{~N}$-depleted values $(8.9 \%$ and $9.1 \%$ ) and one of these (ENT 11) has the most ${ }^{13} \mathrm{C}$-depleted result $(-20.0 \%$ o of all the individuals studied.

\section{Discussion}

\subsection{Breastfeeding and weaning at Ample 1}

The $\delta^{15} \mathrm{~N}$ values of the infants are high as a result of breastfeeding, but individual ENT 9 shows a result $(16.1 \%$ ) that is elevated by approximately $5 \%$ compared to the mean values of the adult population. This is a much larger trophic spacing than normally observed (Fuller et al., 2006a, 2006b), and could suggest that if more individuals from the necropolis were examined, a much wider range of $\delta^{15} \mathrm{~N}$ values might be discovered. It is also possible that this ${ }^{15} \mathrm{~N}$-enriched value might be indicative of sickness or nutritional stress in this infant (e.g. Fuller et al., 2005). The child, ENT 8 aged $4-5$ years old, shows a possible late age of weaning. Similar results have been found in other Roman populations (e.g. Fuller et al., 2006b), but without additional research on a larger number individuals it is impossible to determine the detailed breastfeeding and weaning practices of this population. The two older children (ENT 11 and 21) have lower $\delta^{15} \mathrm{~N}$ values, and this could reflect that there was a different diet for the older children or adolescents, containing less animal protein in the diet (Reitsema and Muir, 2015). However, again a larger and more detailed study is necessary to confirm this interpretation.

\subsection{Marine food consumption at Ample 1}

According to the results presented here, the general pattern of the ancient Mediterranean diet, which is dominated by $\mathrm{C}_{3}$ terrestrial plant foods with the addition of meat in the form of domestic livestock is observed at the Carrer Ample 1 site. However, is interesting to note the elevated $\delta^{15} \mathrm{~N}$ value of the population $(11 \%)$ which is higher than expected given a trophic level spacing of 3-5\% (Lee-Thorp, 2008). Given the small sample size, this could be the result of the fact that the faunal data may not be entirely representative of the animals available for consumption. Still, the ${ }^{15} \mathrm{~N}$-enriched results of two pigs suggest that these animals are capable of having high $\delta^{15} \mathrm{~N}$ values, possible evidence of increased pork consumption at Carrer Ample 1.

However, the consumption of fish appears to have been very slight or entirely absent in this population. According to the archaeological and anthropological data, the population buried at Carrer Am- 
ple 1 had a low socio-economic status (Pujol-Bayona et al., 2011) and during the Roman period, fish were considered expensive food items, suggesting that any regular consumption of fish was possibly restricted to elite members of society (Frayn, 1993; Prowse et al., 2004).

In addition, the prevalence of dental caries observed in the of Carrer Ample 1 population $(24.1 \%)$ is one of the highest for a Roman population from the Iberian East coast, and more resembles a Medieval populations of the same Iberian region (Pujol-Bayona et al., 2011). This high caries rate has been linked to diets high in carbohydrates with only minor amounts of protein intake (Gómez-Bellard and Reverte Coma, 1988; Sealy and van der Merwe, 1988; Littleton and Frohlich, 1993). An inverse correlation between the frequency of caries and marine food consumption was documented in many coastal populations (Walker, 1978; Costa, 1980; Arnay-de-la-Rosa et al., 2009b), because the consumption of protein rich marine foods such as fish contain high levels of fluoride, which can inhibit the formation of caries (Sealy and van der Merwe, 1988). Furthermore, this lack of significant consumption of marine protein is also supported by the fact that isotopic analysis of both modern and archaeological fish bones (grouper, pandora, barracuda and moray eel) from the Mediterranean have ${ }^{13} \mathrm{C}$-enriched $\left(-8.3 \%\right.$ to $-14.1 \%$ ) and ${ }^{15} \mathrm{~N}$-enriched (7.8\%o to $11.4 \%$ ) values (Garcia-Guixé et al., 2010). Thus, we would have expected humans consuming these marine fish to display the typical ${ }^{13} \mathrm{C}$-enrichment that has been documented in other populations (Walker and DeNiro, 1986; Richards et al., 2006). However, it is still possible that marine resources from an estuary setting might have been consumed as organisms such as fish have ${ }^{13} \mathrm{C}$-depleted and ${ }^{15} \mathrm{~N}$-enriched values (e.g. Fuller et al., 2012b). This could account for the elevated $\delta^{15} \mathrm{~N}$ results of the Carrer Ample 1 population, and more research on archaeological nearshore marine fish from the western Mediterranean, and Spain in particular, is necessary.

As noted earlier, garum, or fish sauce, was important in Barcino and fish processing tanks were found at Barcino (Sánchez, 2005; Genera-Monells et al., 2010). Unfortunately, no garum or any other kind of archaeological evidence in support of garum consumption was recovered at Carrer Ample 1, and so it is difficult to determine if it was consumed in significant quantities by the local population. However, garum samples from Italy had a mean $\delta^{15} \mathrm{~N}$ value of $6.5 \pm 1.7 \%$ o and a mean $\delta^{13} \mathrm{C}$ value of $-14.7 \pm 0.6 \%$, suggesting that it was made from lower trophic level species such as sprats (Prowse et al., 2004). If the garum produced at Barcino was isotopically similar to the Italian garum, then it is possible that the inhabitants of Carrer Ample 1 also consumed this dietary item in addition to $\mathrm{C}_{3}$ terrestrial plant and animal proteins. This might be expected given the coastal location of the Carrer Ample 1 site, but clear evidence of higher trophic level marine protein consumption is lacking in the collagen $\delta^{13} \mathrm{C}$ and $\delta^{15} \mathrm{~N}$ results.

\subsection{Carrer Ample 1 vs. other coastal Roman sites}

It is valuable to compare the Carrer Ample 1 results in relation to previous studies from other Roman sites, notably the coastal Mediterranean sites of Leptiminus, Isola Sacra, Velia and Poundbury, from the northwest coast of the Roman Europe.

Leptiminus was a Roman city on the Mediterranean coast of Tunisia dated from the 2 nd to 5 th centuries AD, in which the archaeological evidence suggests that both wealthy and lower status individuals were buried in the cemetery (Keenleyside et al., 2009).

Isola Sacra was a Roman necropolis situated outside Portus, the port city of Rome, Italy (Prowse, 2001; Prowse et al., 2004, 2005). The necropolis was active from the 1 st to 3 rd centuries AD and was a key center of trading for the Roman Empire and was directly linked to the city of Rome (Prowse et al., 2004, 2005). The inhabitants of Portus were mostly middle-class administrators, traders, and merchants (Mannucci and Verduchi, 1996).

Velia was a Roman city situated to the south of Portus. The economy of Velia was mainly centered upon the port activities of the city (Morel, 1999; Craig et al., 2009). The necropolis was situated adjacent to the port, just outside the south entrance of the city (Porta Marina $\mathrm{Sud}$ ), being active from the 1 st to 2 nd centuries $\mathrm{AD}$. It contained both inhumations and cremations, displaying a great variety of tomb typology (including mausoleums), but the grave-goods do not suggest high prestige and overall the assemblages were not indicative of social asymmetry or class distinction within the necropolis (Craig et al., 2009).

In contrast, Poundbury was a large cemetery close to the Roman town of Durnovaria, Dorchester, U.K (Richards et al., 1998). The human remains of this cemetery date from the Iron Age until the Early Post-Roman period. The majority of the burials from the Late Roman period belong to the 4th century AD (Farwell and Molleson, 1993). As well as varied tomb types (including mausoleums), the grave-goods do suggest that the Poundbury cemetery population featured both wealthy and lower status social classes (Richards et al., 1998).

The anthropological and archaeological data from Carrer Ample 1 , suggest that the individuals were not wealthy or privileged elites of Roman society. The paleopathological markers (stature, hypoplasia and growth) of the skeletons, the simple typology of the tombs and the absence of grave-goods are indicative of low socio-economic position of the individuals from Ample 1. In addition, the great distance between the location of the Carrer Ample 1 tombs and the Sea Gate of Barcino also supports the idea of a low socio-economic position of its population since individuals having an important social status were always buried close the city gates in Roman times (Prida, 2009). Therefore, there are strong indications that the individuals of Carrer Ample 1 were lower class individuals, possibly, slaves or free peasants serving in a late Roman Villae in the suburbium of Barcino (Pujol-Bayona et al., 2011).

Examination of the adult mean $\pm \mathrm{SD}$ isotopic results from the five sites reveals a strong linear trend (Fig. 4) indicating dietary diversity was prevalent in these different regions of the coastal Roman world. Leptiminus has the highest mean values for both $\delta^{13} \mathrm{C}$

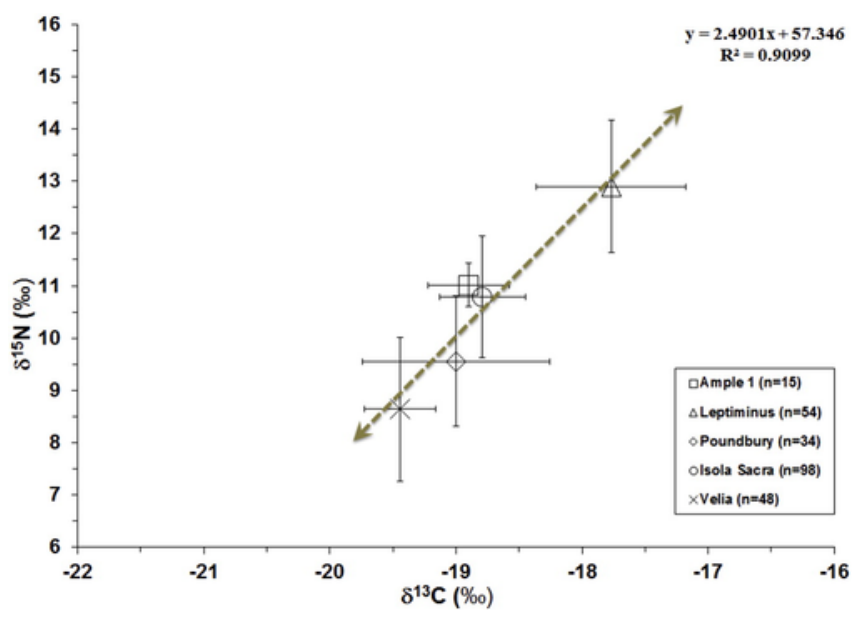

Fig. 4. Plot of mean $\delta^{13} \mathrm{C}$ and $\delta^{15} \mathrm{~N}$ values for the sites of Carrer Ample 1, Spain Leptiminus, Tunisia (Keenleyside et al., 2009), Isola Sacra, Italy (Prowse et al., 2004, 2005), Poundbury Camp, UK (Richards et al., 1998), and Velia, Italy (Craig et al., 2009). 
$(-17.8 \pm 0.6 \%)$ and $\delta^{15} \mathrm{~N}(12.9 \pm 1.3 \%$ ) while Velia has the lowest $\delta^{13} \mathrm{C}(-19.4 \pm 0.3 \% \circ)$ and $\delta^{15} \mathrm{~N}(8.6 \pm 1.4 \% o)$ results of the populations studied (see Table 4 and Fig. 4). The $\delta^{13} \mathrm{C}$ and $\delta^{15} \mathrm{~N}$ values of Leptiminus are followed by those of Isola Sacra $\left(\delta^{13} \mathrm{C}=-18.8 \pm 0.3 \% \circ ; \delta^{15} \mathrm{~N}=10.8 \pm 1.2 \% 0\right)$ and Carrer Ample 1 $\left(\delta^{13} \mathrm{C}=-18.9 \pm 0.3 \% \circ ; \delta^{15} \mathrm{~N}=11.0 \pm 0.4 \% o\right)$, and no significant differences were observed between these sites when a one-way ANOVA test was applied (Table 4, Fig. 4). Late Roman Poundbury has lower $\delta^{13} \mathrm{C}(-19.0 \pm 0.7 \% \circ)$ and $\delta^{15} \mathrm{~N}(9.6 \pm 1.3 \%$ ) values than Isola Sacra, and Carrer Ample 1, but the large overlap in the $\delta^{13} \mathrm{C}$ standard deviations between the three sites confirms that there are no significant differences (Table 4). However, the Poundbury mean $\delta^{15} \mathrm{~N}$ value was found to be significantly lower than both Isola Sacra and Carrer Ample 1 (Table 4). These results could suggest that Leptiminus and then Isola Sacra appear to have had the highest consumption of marine protein. This was followed by Carrer Ample 1, Poundbury and finally Velia in order of importance, although clear evidence for marine diets was found in some individuals (elites buried in mausoleums) at Poundbury (Richards et al., 1998) and at Velia (Craig et al., 2009).

The fact that the Leptiminus, Isola Sacra and Poundbury sites included higher status and wealthy individuals could be one possible explanation for the dietary differences between these populations and Velia and Carrer Ample 1 in relation to fish consumption. It is also possible that the dietary differences of the populations of Leptiminus, Isola Sacra and Late Roman Poundbury can be explained by regional isotopic differences in dietary diversity. However, in comparing these four Mediterranean Roman sites and Poundbury, which is situated on the Atlantic southwest coast of England, we must also recognize the possible effect on $\delta^{13} \mathrm{C}$ values of plant food sources being lower by $1-2 \%$ in northern Europe compared to Mediterranean regions (Richards and van Klinken, 1995). In addition, isotopic differences between Atlantic and Mediterranean fish should be considered. Although the two regions can have variable isotopic results related to local environmental conditions, the fish from the Atlantic appear more ${ }^{13} \mathrm{C}$ - and ${ }^{15} \mathrm{~N}$-enriched (Arnai-de-la-Rosa et al., 2010) than those of the Mediterranean (Garcia-Guixé et al., 2010). Future studies that examine archaeological fish stable isotope remains from different parts of coastal Europe are needed to better understand these findings.

Finally, while only a small number of individuals were studied at Barcino, an absence of significant sex differences in the $\delta^{13} \mathrm{C}$ and $\delta^{15} \mathrm{~N}$ values at Carrer Ample 1 is observed (Tables 1 and 3, Fig. 3), and this suggests that both men and women consumed similar foods.

Table 3

Male vs. female $\delta^{13} \mathrm{C}$ and $\delta^{15} \mathrm{~N}$ results for the sites of Carrer Ample 1, Leptiminus, Poundbury Camp, Velia, and Isola Sacra.

\begin{tabular}{|c|c|c|c|c|c|c|c|}
\hline Site & Sex & $\mathrm{n}$ & $\begin{array}{l}\delta^{13} \mathrm{C} \\
(\% o)\end{array}$ & $\pm \mathrm{SD}$ & $\mathrm{n}$ & $\begin{array}{l}\delta^{15} \mathrm{~N} \\
(\% o)\end{array}$ & $\pm \mathrm{SD}$ \\
\hline \multirow[t]{2}{*}{ Carrer Ample 1 - Spain } & Male & 10 & -18.8 & 0.4 & 10 & 10.9 & 0.4 \\
\hline & Female & 5 & -19.0 & 0.2 & 5 & 11.1 & 0.5 \\
\hline \multirow{2}{*}{$\begin{array}{l}\text { Leptiminus - Tunisia } \\
\text { (Keenleyside et al., 2009) }\end{array}$} & Male & 16 & -17.7 & 0.7 & 16 & 13.0 & 1.3 \\
\hline & Female & 20 & -17.8 & 0.5 & 20 & 13.0 & 1.5 \\
\hline \multirow{2}{*}{$\begin{array}{l}\text { Late Roman Poundbury - UK } \\
\text { (Richards et al., 1998) }\end{array}$} & Male & 20 & -18.9 & 0.7 & 20 & 10.1 & 0.9 \\
\hline & Female & 14 & -19.1 & 0.8 & 14 & 8.7 & 1.3 \\
\hline \multirow{2}{*}{$\begin{array}{l}\text { Velia - Italy (Craig et al., } \\
\text { 2009) }\end{array}$} & Male & 25 & -19.3 & 0.2 & 25 & 9.0 & 1.5 \\
\hline & Female & 22 & -19.6 & 0.3 & 22 & 8.1 & 0.8 \\
\hline \multirow{2}{*}{$\begin{array}{l}\text { Isola Sacra - Italy (Prowse et } \\
\text { al., 2005) }\end{array}$} & Male & 48 & -18.7 & 0.3 & 49 & 11.0 & 1.1 \\
\hline & Female & 32 & -18.8 & 0.3 & 30 & 10.6 & 1.0 \\
\hline
\end{tabular}

This finding is in agreement with the isotopic results from Leptiminus (Keenleyside et al., 2009) but differs in regard to those from Late Roman Poundbury, Velia and Isola Sacra. Although Richards et al. (1998) did not find sex differences for $\delta^{13} \mathrm{C}$ and $\delta^{15} \mathrm{~N}$ between males and females in Late Roman and Post Roman burials from Poundbury when they were analyzed together, we found significant sex differences in $\delta^{15} \mathrm{~N}\left(\mathrm{t}=3.572 \mathrm{p}=0.001^{*}\right)$ when the Late Roman burials were analyzed separately (Table 3 ). In the case of Isola Sacra, overall results indicated that females have $\delta^{13} \mathrm{C}$ values lower than males and similar values for $\delta^{15} \mathrm{~N}$ (Prowse et al., 2005). However when the data were analyzed taking into account age categories, the $\delta^{15} \mathrm{~N}$ values were consistently higher among males than females (Prowse et al., 2005). In the case of Velia the individuals with higher values of $\delta^{13} \mathrm{C}$ and $\delta^{15} \mathrm{~N}$ were mostly males (Craig et al., 2009). These sexual differences have been interpreted as reflecting greater consumption of terrestrial $\mathrm{C}_{3}$ foods by females and less consumption of marine foods compared to males (Prowse et al., 2005; Craig et al., 2009). It is clear that more isotopic work should be directed toward additional Roman sites, especially in Spain, to better understand how dietary practices were influenced by gender.

\section{Conclusions}

This preliminary project reports carbon and nitrogen isotope ratios on skeletons recovered from a Roman archaeological population on the mainland of Spain to examine human diet at the site of Carrer Ample 1 in Barcelona. It was revealed that the humans had a $\mathrm{C}_{3}$ terrestrial diet that was based on domestic animals, with pigs and sheep/goat likely providing the bulk of the dietary animal protein, and with cattle, red deer, and chicken consumed on a less frequent basis. No dietary differences were observed between the sexes and the youngest infants and children displayed ${ }^{15} \mathrm{~N}$-enriched values characteristic of breastfeeding. The results of the present study also highlight that regional variability in diet existed within the Roman Empire, and suggests that north of Africa is one of the regions in which there was more consumption of fish. However, given the large number of archaeological sites in Spain it is clear that much more work needs to be done with increased sampling of urban and rural burial populations from the Roman Period, and this is an area of active research.

\section{Uncited references}

Gurt-Esparraguera and Godoy-Fernández, 2000

Jones, 1953

\section{Table 4}

$\mathrm{p}$ values obtained by applying an ANOVA test to $\delta^{13} \mathrm{C}$ and $\delta^{15} \mathrm{~N}$ values from the sites of Carrer Ample 1, Leptiminus (Keenleyside et al., 2009), Isola Sacra (Prowse et al., 2004 2005), Poundbury Camp (Richards et al., 1998), and Velia (Craig et al., 2009). The statistical significance is indicated by $(*)$.

\begin{tabular}{lllll}
\hline & Carrer Ample 1 & Leptiminus & Isola Sacra & Poundbury \\
\hline$\delta^{13} \mathrm{C}(\% \circ)$ & & & & \\
$\quad$ Carrer Ample 1 & & & & \\
Leptiminus & $0.000^{*}$ & & & \\
Isola Sacra & 0.897 & $0.000^{*}$ & & $0.002 *$ \\
Poundbury & 0.937 & $0.000^{*}$ & 0.999 & \\
Velia & $0.005^{*}$ & $0.000^{*}$ & $0.000^{*}$ & \\
$\delta^{15} \mathrm{~N}(\%)$ & & & & \\
Carrer Ample 1 & & & & \\
Leptiminus & $0.000^{*}$ & & & \\
Isola Sacra & 0.920 & $0.000^{*}$ & & \\
Poundbury & $0.001 *$ & $0.000^{*}$ & $0.000^{*}$ & \\
Velia & $0.000^{*}$ & $0.000^{*}$ & $0.000^{*}$ & $0.025^{*}$ \\
\hline
\end{tabular}


Schoeninger, 1995

Van der Veen et al., 1996

\section{Acknowledgements}

The authors would like to thank to the Museu de Història de la Ciutat de Barcelona for allowing the present study. The Max Planck Society is thanked for funding this study and the authors acknowledge the support of J.J. Hublin. This study was also supported by the National Natural Science Foundation of China Research Fund for International Young Scientists (41550110224), and the Chinese Academy of Sciences International Visiting Scholar Fellowship (2016VBC002). L. Lloveras was funded by a postdoctoral grant (BP-A 00334 2011) from the Secretaria d'Universitats i Recerca del Departament d'Economia i Coneixement de la Generalitat de Catalunya, Spain.

\section{References}

Alcock, J.P., 2006. Food in the Ancient World. Greenwood Press, Connecticut. Alonso, N., 2000. Registro arqueobotánico de Cataluña occidental durante el II y I milenio a.n.e. Complutum. 11, 221-238.

Álvarez, R., Estrada, A., 2009. L'explotació de ferro en el complex miner de Gavà. La mina número 65. L'Arqueologia a Gavà Homenatge a Alícia Estrada. In: Col-lecció la nostra gent (Ajuntament de Gavà). 5, pp. 141-160.

Arias, P., Schulting, R.J., 2010. Análisis de isótopos estables sobre los restos humanos de La Braña-Arintero. Aproximación a la dieta de los grupos mesolíticos de la cordillera cantábrica. In: Vidal, J.M., Prada, M.E. (Eds.), Los Hombres Mesoliticos de la cueva La Braña-Arintero (Valdelugueros, León). Diputación de León, León, pp. 130-137.

Arnai-de-la-Rosa, M., González-Reimers, E., Yanes, Y., Velasco-Vázquez, J., Romanek, C.S., Noakes, J.E., 2010. Paleodietary analysis of the prehistoric population of the Canary Islands inferred from stable isotopes (carbon, nitrogen and hydrogen) in bone collagen. Am. J. Phys. Anthropol. 37, 1490-1501.

Arnay-de-la-Rosa, M., González-Reimers, E., Gámez-Mendoza, A., Galindo-Martín, L., 2009. The $\mathrm{Ba} / \mathrm{Sr}$ ratio, carious lesions, and dental calculus among the population buried in the church La Concepción (Tenerife, Canary Islands). J. Archeol. Sci. 36, 351-358.

Bordas, A., Molinas, R., Saa, M., Melgarejo, J.C., Lehbib, S., 2009. Les mines històriques al sector de la Serra de les Ferreres: darreres aportacions a l'estudi de la mineria del Ferro a Gavà. Rubricatum. 4, 247-262.

Brickley, M., Mckinley, J.I., 2004. Guidelines to the Standards for Recording Human Remains. IFA/BABAO.

Brown, T.A., Nelson, D.E., Vogel, J.S., Southon, J.R., 1988. Improved collagen extraction by modified Longin method. Radiocarbon 30, 171-177.

Buikstra, J.E., Ubelaker, D.H., 1994. Standards for data collection from human skeletal remains. In: Arkansas Archeological Survey Research Series No. 44, Fayetteville.

Canti, M., Huisman, D.J., 2015. Scientific advances in geoarchaeology during the last twenty years. J. Archaeol. Sci. 56, 96-108.

Cheung, C., Schroeder, H., Hedges, R.E.M., 2012. Diet, social differentiation and cultural change in Roman Britain: new isotopic evidence from Gloucestershire. Archaeol. Anthropol. Sci. 4, 61-73.

Cool, H.E.M., 2006. Eating and Drinking in Roman Britain. Cambridge University Press, Cambridge.

Costa, R.L., 1980. Incidence of caries and abscesses in archaeological Eskimo skeletal samples from point hope and Kodiak Island, Alaska. Am. J. Phys. Anthropol. 52, 501-514

Craig, O.E., Biazzo, M., O'Connell, T.C., Garnsey, P., Martinez-Labarga, C., Lelli, R. Salvadei, L., Tartaglia, G., Nava, A., Reno, L., Fiammenghi, A., Rickards, O., Bondioli, L., 2009. Stable isotopic evidence for diet at the imperial roman costal site of Velia (1st and 2nd centuries AD) in southern Italy. Am. J. Phys. Anthropol. 139, 572-583.

Crowe, F., Sperduti, A., O'Connell, T.C., Craig, O.E., Kirsanow, K., Germoni, P. Macchiarelli, R., Garnsey, P., Bondioli, L., 2010. Water-related occupations and diet in two roman coast communities (Italy, first to third century AD): correlation between stable carbon and nitrogen isotope values and auricular exostosis prevalence. Am. J. Phys. Anthropol. 142, 355-366.

Dalby, A., 2003. Food in the Ancient World from A to Z. Routledge, London.

Davis, M.H.L.A., 2002. Putting meat on the bone: an investigation into palaeodiet in the Balearic Islands using carbon and nitrogen stable isotope analysis. In: WH, W., Ensenyat, J. (Eds.), World Islands in Prehistory: International Insular Investigations. V Deia International Conference of Prehistory. British Archaeological Reports International Series 1095, Oxford pp. 198-216.
DeNiro, M.J., 1985. Postmortem preservation and alteration of in vivo bone collagen isotope ratios in relation to palaeodietary reconstruction. Nature $317,806-809$.

Dunbabin, K.M.D., 2003. The Roman Banquet: Images of Conviviality. Cambridge University Press, Cambridge.

Dupras, T.L., Tocheri, M.W., 2007. Reconstructing infant weaning histories at Roman period Kellis, Egypt, using stable isotope analysis of dentition. Am. J. Phys. Anthropol. 134, 63-74.

Dupras, T.L., Schwarcz, H.P., Fairgrieve, S.I., 2001. Infant feeding and weaning practices in Roman Egypt. Am. J. Phys. Anthropol. 115, 204-212.

Faas, P., 1994. Around the Roman Table: Food and Feasting in Ancient Rome. University of Chicago Press, Chicago.

Farwell, D.E., Molleson, T.I., 1993. Excavations at Poundbury, Dorset 1966-1982. Volume II: The Cemeteries. Dorset Natural History and Archaeological Society Monograph Series Number 7.

Fernandez-Rodríguez, C., Ramil-Rego, P., Rodríguez-López, C., 1998. La dieta alimenticia desde la Prehistoria a la Edad Media en el Noroeste Ibérico. En VVAA: V e VI Semanas Galegas de Historia: Morte e sociedade no Noroeste Peninsular/ Un percorrido pola Galicia cotiá. Asociación Galega de Historiadores, Noia, 277-312.

Frayn, J.M., 1993. Markets and Fairs in Roman Italy: Their Importance from the Second Century BC to the Third Century. OUP Catalogue.

Froehle, A.W., Kellner, C.M., Schoeninger, M.J., 2010. Effect of diet and protein source on carbon stable isotope ratios in collagen. J. Archaeol. Sci. 37, 2662-2670.

Fuertes-Prieto, M.N., Fernández-Rodríguez, C., 2010. Trade and consumption of shellfish during roman times at Asturica Augusta (León, Spain). In: Lugo: Férvedes Vilalba. 6, pp. 147-158.

Fuller, B.T., Cupere, B., Marinova, E., Van Neer, W., Waelkens, M., Richards, M.P., 2012. Isotopic reconstructions of human diet and animal husbandry practices during the classical-Hellenistic, imperial, and byzantine periods at Sagalassos. Am. J. Phys. Anthropol. 149, 157-171.

Fuller, B.T., Fuller, J.L., Harris, D.A., Hedges, R.E.M., 2006. Detection of breastfeeding and weaning in modern human infants with carbon and nitrogen stable isotope ratios. Am. J. Phys. Anthropol. 129, 279-293.

Fuller, B.T., Fuller, J.L., Sage, N.E., Harris, D.A., O'Connell, T.C., Hedges, R.E.M., 2005. Nitrogen balance and $\delta^{15} \mathrm{~N}$ : why you are not what you eat during nutritional stress. Rapid Commun. Mass Spectrom. 19, 2497-2506.

Fuller, B.T., Márquez-Grant, N., Richards, M.P., 2010. Investigation of diachronic dietary patterns on the islands of Ibiza and Formentera, Spain: evidence from carbon and nitrogen stable isotope ratio analysis. Am. J. Phys. Anthropol. 143, 512-522.

Fuller, B.T., Molleson, T.I., Harris, D.A., Gilmour, L.T., Hedges, R.E.M., 2006. Isotopic evidence for breastfeeding and possible adult dietary differences from Late/ Sub-Roman Britain. Am. J. Phys. Anthropol. 129, 45-54.

Fuller, B.T., Müldner, G., Van Neer, W., Ervynck, A., Richards, M.P., 2012. Carbon and nitrogen stable isotope ratio analysis of freshwater, brackish and marine fish from Belgian archaeological sites (1st and 2nd millennium AD). J. Anal. Atom. Spectrom. 27, 807-820

Garcia, E., Subirá, M.E., Richards, M.P., 2004. Régime et société d'après l'analyse des isotopes stables: l'exemple de la population de «Can Reiné» (Mallorca. Espagne, 600 ap. J.C.). Anthropos 7, 171-176.

Garcia-Guixé, E., Subirá, M.E., Marlasca, R., Richards, M.P., 2010. $\delta^{13} \mathrm{C}$ and $\delta^{15} \mathrm{~N}$ in ancient and recent fish bones from the Mediterranean Sea. J. Nord. Archaeol. Sci. 17, 83-92.

Garnsey, P., 1999. Food and Society in Classical Antiquity. Cambridge University Press, Cambridge.

Garvie-Lok, S., 2001. Loaves and fishes: a stable isotope reconstruction of diet in Medieval Greece. Ph.D. thesis Department of Anthropology, University of Calgary, Canada.

Genera-Monells, M., Orri-Terrado, E., Nadal-Lorenzo, J., 2010. Datos para una aproximación a las prácticas culinarias en la antigua ciudad de Dertosa: el solar de la Costa dels Capellans núm. 5, Tortosa (Baix Ebre). Saguntum 9, 257-262.

Giacosa, I.G., 1994. A Taste of Ancient Rome. University of Chicago Press, Chicago.

Gómez-Bellard, F., Reverte Coma, J.M., 1988. Análisis antropológico y paleopatológico de los restos óseos humanos de Ca Na Costa (Formentera), Parte 2. In: J.H., F., Plantalamor, L., Topp, C., Gómez-Bellard, F., Reverte Coma, J.M. (Eds.), El Sepulcro Megalítico de Ca Na Costa. 19. Trabajos del Museo Arqueológico de Ibiza, Ibiza, pp. 55-76.

Gurt-Esparraguera, J.M., Godoy-Fernández, C., 2000. Barcino, de sede imperial a vrbs regia en época visigoda. Memorias de la Real Academia de Buenas Letras de Barcelona. 5, 400-800.

Hedges, R.E.M., Clement, J.G., Thomas, C.D.L., O'Connell, T.C., 2007. Collagen turnover in the adult femoral mid-shaft: modeled from anthropogenic radiocarbon tracer measurements. Am. J. Phys. Anthropol. 133, 808-816.

Hernández, F.X., 2001. Història d'una ciutat. Llibres de l'Índex, Barcelona

Jones, W.H.S., 1953. Natural History. vol. 8. Harvard University Press, Cambridge. Translation of Pliny's Historia Naturalis.

Juárez-Arroyo, T., 2009. Memòria de la intervenció arqueològica al C/Nou de Sant Francesc, 9-13C/Còdols, 22, C/d'en Rull, 10-14. 11 desembre 2006 al 17 gener 2007. Generalitat de Catalunya, Barcelona. 
Katzenberg, M.A., 2000. Stable isotope analysis: a tool for studying past diet, demography, and life history. In: Katzenberg, M.A., Saunders, S.R. (Eds.), Biological Anthropology of the Human Skeleton. Wiley-Liss, New York, pp. 305-327.

Keay, S., 1984. Late Roman amphorae in the western Mediterranean: a typology and economic study. In: The Catalan Evidence. British Archaeological Reports International Series, 196. Archaeopress, Oxford.

Keenleyside, A., Schwarcz, H., Stirling, L., Lazreg, N.B., 2009. Stable isotopic evidence for diet in a Roman and Late Roman population from Leptiminus, Tunisia. J. Archaeol. Sci. 36, 51-63.

Killgrove, K., Tykot, R.H., 2013. Food for Rome: a stable isotope investigation of diet in the imperial period (1st-3rd centuries AD). J. Anthropol. Archaeol. 32, $28-38$.

King, A., 1999. Diet in the roman world: a regional inter-site comparison of the mammal bones. J. Roman Archaeol. 12, 168-202.

Lee-Thorp, J.A., 2008. On isotopes and old bones. Archaeometry 50, 925-950.

Littleton, J., Frohlich, B., 1993. Fish-eaters and farmers: dental pathology in the Arabian gulf. Am. J. Phys. Anthropol. 92, 427-447.

López-Costas, O., 2012. Antropología de los restos óseos humanos de Galicia: Estudio de la población romana y medieval gallega. In: Ph.D Thesis Disertation. Universidad de Granada, Granada, Spain.

MacKinnon, M., 2004. Production and consumption of animals in roman Italy: integrating the zooarchaeological and textual evidence. J. Roman Archaeol. Sup. 54

Mannucci, V., Verduchi, P., 1996. Il porto imperiale di Roma: le vicende storiche. In: Mannucci, V. (Ed.), Il Parco Archeologico Naturalistico del Porto di Traiano. Gangemi Editore, Roma, pp. 15-28.

Márquez-Grant, N., Fuller, B., Richards, M.P., 2003. Análisis de patrones de dieta en restos humanos de la isla de Ibiza a partir del contenido de los isótopos estables de carbono, nitrógeno y azufre. In: Aluja, M.P., Malgosa, A., Nogués, R. (Eds.), Antropología y Biodiversidad. Ediciones Bellaterra, Barcelona, pp. 352-356.

Mattingly, D.J., 2006. The Garamantes: the first Libyan state. In: The Libyan Desert. Natural Resources and Cultural Heritage. Society for Libyan Studies, London, pp. 189-204

Mays, S., 1998. The Archaeology of Human Bones. Routledge/English Heritage, London.

Morel, J.P., 1999. Hyélè revue à la lumière de Massalia. In: Krinzinger, F., Tocco, G. (Eds.), Neue Forschungen in Velia. Akten des Kongresses "La ricerca archeological a Velia”. Austria Academy of Sciences Press, Vienna, pp. 11-12. Rome, 1.-2. Juli 1993.

Müldner, G., 2013. Stable isotopes and diet: their contribution to Romano-British research. Antiquity 87, 137-149.

Müldner, G., Richards, M.P., 2007. Stable isotope evidence for 1500 years of human diet at the city of York, UK. Am. J. Phys. Anthropol. 133, 682-697.

Murray, M., Schoeninger, M., 1988. Diet, status, and complex social structure in Iron Age Central Europe: some contributions of bone chemistry. In: Gibson, D., Geselowitz, M. (Eds.), Tribe and Polity in Late Prehistoric Europe. Plenum Press, London, pp. 155-176.

Nehlich, O., Fuller, B.T., Márquez-Grant, N., Richards, M.P., 2012. Investigation of diachronic dietary patterns on the Islands of Ibiza and Formentera, Spain: evidence from sulfur stable isotope ratios analysis. Am. J. Phys. Anthropol. 149, 115-124.

Prida, D., 2009. Memòria arqueològica de la intervenció efectuada al CA1 de Barcelona Generalitat de Catalunya, Barcelona.

Prowse, T.L., 2001. Isotopic and Dental Evidence for Diet from the Necropolis of Isol Sacra (1st-3rd Centuries AD), Italy. Ph.D. dissertation McMaster University.

Prowse, T.L., Saunders, S.R., Schwarcz, H.R., Garnsey, P., Macchiarelli, R., Bondioli, L., 2008. Isotopic and dental evidence for infant and young child feeding practices in an imperial roman skeletal sample. Am. J. Phys. Anthropol. 137, 294-308.

Prowse, T.L., Schwarcz, H.P., Saunders, S.R., Macchiarelli, R., Bondioli, L., 2004. Isotopic paleodiet studies of skeletons from the imperial roman-age cemetery of Isola Sacra, Rome, Italy. J. Archaeol. Sci. 31, 259-272.

Prowse, T.L., Schwarcz, H.P., Saunders, S.R., Macchiarelli, R., Bondioli, L., 2005. Isotopic evidence for age-related variation in diet from Isola Sacra. Am. J. Phys. Anthropol. 128, 2-13.

Pujol-Bayona, A., Rissech, C., Prida, D., Turbón, D., 2011. Estudio bioantropológico del conjunto funerario de época tardorromana Carrer Ample 1 de Barcelona. Rev. Esp. Antrop. Fís. 32, 1-19.

Purcell, N., 2003. The way we used to eat: diet, community, and history at Rome. Am. J. Philol. 124, 329-358.

Redfern, R.C., Hamlin, C., Bevan-Athfield, N., 2010. Temporal changes in diet: a stable isotope analysis of late iron age and roman Dorset, Britain. J. Archaeol. Sci. 37, 1149-1160.

Reitsema, L.J., 2013. Beyond diet reconstruction: stable isotope applications to human physiology, health, and nutrition. Am. J. Hum. Biol. 25, 445-456.

Reitsema, L.J., 2015. Laboratory and field methods for stable isotope analysis in human biology. Am. J. Hum. Biol. 27, 593-604.

Reitsema, L.J., Muir, A.B., 2015. Growth velocity and weaning $\delta^{15} \mathrm{~N}$ "Dips" during ontogeny in Macacamulatta. Am. J. Phys. Anthropol. 157, 347-357.
Richards, M.P., Hedges, R.E.M., 1999. Stable isotope evidence for similarities in the types of marine foods used by late Mesolithic humans at sites along the Atlantic coast of Europe. J. Archaeol. Sci. 26, 717-722.

Richards, M.P., van Klinken, G.J., 1995. A survey of European human bone stable carbon and nitrogen isotope values. In: Sinclair, A.G.M., Slate, E.A., Gowlett, J.A.J. (Eds.), Archaeological Sciences 1995. Oxbow Archaeological Monograph. Oxbow Books, Oxford, pp. 363-368.

Richards, M.P., Fuller, B.T., Molleson, T.I., 2006. Stable isotope palaeodietary study of humans and fauna from the multi-period (Iron Age, Viking and late Medieval) site of Newark Bay, Orkney. J. Archaeol. Sci. 33, 122-131.

Richards, M.P., Hedges, R.E.M., Molleson, T.I., Vogel, J.C., 1998. Stable isotope analysis reveals variations in human diet at the Poundbury Camp cemetery site. J. Archaeol. Sci. 25, 1247-1252.

Rissech, C., Estabrook, E.F., Cunha, E., Malgosa, A., 2006. Using the acetabulum to estimate age at death in adult males. J. Forensic Sci. 51, 213-229.

Rissech, C., Estabrook, E.F., Cunha, E., Malgosa, A., 2007. Estimation of age at death for adult males using the acetabulum, applied to four Western European collections. J. Forensic Sci. 52, 774-778.

Rissech, C., Márquez-Grant, N., Turbón, D., 2013. A collation of recently published Western European formulae for age estimation of subadult skeletal remains: recommendations for forensic anthropology and osteoarchaeology. J. Forensic Sci. 58, 163-168.

Salazar-García, D.C., Aura, E., Olària, C., Talamo, S., Morales, J.V., Richards, M.P., 2014. Isotope evidence for the use of marine resource in Eastern Iberian Mesolithic. J. Archaeol. Sci. 42, 231-240.

Salazar-García, D.C., Benítez, L.B., Álvarez, H.J., Benito, M., 2013. Estudio diacrónico de la dieta de los pobladores antiguos de Terrinches (Ciudad Real) a partir del análisis de isótopos estables sobre restos óseos humanos. Rev. Esp. Antrop. Fís. 34, 6-14.

Salazar-García, D.C., Romero, A., García-Borja, P., Subirà, E., Richards, M.P., 2016. A combined dietary approach using isotope and dental buccal-microwear analysis of humans from the Neolithic, Roman and Medieval periods from archaeological site of Tossal de les Basses (Alicante, Spain). J. Archaeol. Sci. 6, 610-619.

Sánchez, A., 2005. Mortero romano. Pieza del Mes-Ciclo 2005 Ajuar de cocina y ajuar de mesa: La alimentación. Museo Arqueológico Nacional, Madrid.

Schoeninger, M.J., 1995. Stable isotope studies in human evolution. Evolutionary Anthropology 4, 83-98.

Schoeninger, M., Moore, K., 1992. Bone stable isotope studies in archaeology. J. World Prehist. 6, 247-296.

Sealy, J.C., van der Merwe, N.J., 1988. Social, spatial and chronological patterning in marine food use as determined by $\delta^{13} \mathrm{C}$ measurements of Holocene human skeletons from the southwestern Cape, South Africa. World Archaeol. 20, 87-102.

Stenhouse, M.J., Baxter, M.S., 1979. The uptake of bomb ${ }^{14} \mathrm{C}$ in humans, in radiocarbon dating. In: Berger, R., Suess, H.E. (Eds.), Radiocarbon Dating. University of California Press, Berkeley, pp. 324-341.

Triay-Oliver, V., 2006. Memòria arqueològica de la intervenció efectuada al carrer Ample, 5 de Barcelona (El Barcelonès). 2004. Generalitat de Catalunya, Barcelona.

Van der Veen, M., 2008. Food as embodied material culture: diversity and change in plant food consumption in Roman Britain. J. Roman Archaeol. 21, 83-110.

Van der Veen, M., Grant, M., Barker, G., 1996. Romano-Libyan agriculture: crops and animals. In: Barker, G. (Ed.), Synthesis. Farming the Desert: The UNESCO Libyan Valleys Archaeological Survey. vol. 1. UNESCO Publications, Paris, pp. 227-264.

Van Strydonck, M., Boudin, M., Ervynck, A., 2002. Stable isotopes $\left({ }^{13} \mathrm{C}\right.$ and $\left.{ }^{15} \mathrm{~N}\right)$ and diet: animal and human bone collagen from prehistoric sites in Mallorca, Menorca and Formentera (Balearic Islands, Spain). In: WH, W., Ensenyat, J. (Eds.), World Islands in Prehistory: International Insular Investigations. V Deià International Conference of Prehistory. British Archaeological Reports International Series 1095, Oxbow books, Oxford, pp. 189-197.

Van Strydonck, M., Boudini, M., Ervynck, A., Orvay, J., Borms, H., 2005. Spatial and temporal variation of dietary habits during the prehistory of the Balearic Islands as reflected by ${ }^{14} \mathrm{C}, \delta^{15} \mathrm{~N}$ and $\delta^{13} \mathrm{C}$ analyses on human and animal bones. Mayurqa 30, 523-541.

Walker, P.L., 1978. A quantitative analysis of dental attrition rate in the Santa Barbara channel area. Am. J. Phys. Anthropol. 48, 101-106.

Walker, P.L., DeNiro, M.J., 1986. Stable nitrogen and carbon isotope ratios in bone collagen as indices of prehistoric dietary dependence on marine and terrestrial resources in southern California. Am. J. Phys. Anthropol. 71, 51-61.

Wilkins, J., Hill, S., 2006. Food in the Ancient World. Blackwell, Oxford.

Woolf, G., 1998. Becoming Roman: The Origins of Provincial Civilization in Gaul. Cambridge University Press, Cambridge. 